The International Journal of Critical Media Literacy 


\title{
The International Journal of Critical Media Literacy
}

\author{
Editors-in-Chief
}

William M. Reynolds, Georgia Southern University

Brad Porfilio, Seattle University

\section{Editorial Board}

Vonzell Agosto, University of South Florida, USA

Donna Alvermann, University of Georgia, USA

Matthew Attencio, California Sate East Bay, USA

Lori Bindig, Sacred Heart University, USA

Allison Butler, University of Massachusetts Amherst, USA

Paul Chamness Miller-Kuriyama, Akita International University, Japan

Warren Chrichlow, York University, Canada

Anna Cruz, St. Louis Community College, UsA

Arnold Danzig, California State University Santa Cruz, USA

Derek Ford, DePauw University, USA

Julie Frechette, Worchester State University, USA

Aristotelis Gkiolmas, University of Athens, Greece

Douglas Kellner, UCLA, USA

Daniel Liou, Arizona State University, USA

Brian Lozenski, Macalester University, USA

Johnny Lupinacci, Washington State University, USA

Tyson Marsh, Seattle University, USA

Peter McLaren, Chapman University, USA

Debangshu Roygarner, CUNY Graduate Center, USA

Lauren Roygarner, CUNY Graduate Center, USA

Jeff Share, UCLA, USA

Shirley Steinberg, University of Calgary, Canada

Lisa William-White, California State East Bay, USA

William Yousman, Sacred Heart University, USA

Volumes published in this journal are listed on $\mathrm{brill.com} / \mathrm{jcml}$ 


\section{The International Journal of Critical Media Literacy}

VOLUME 3 (2021)

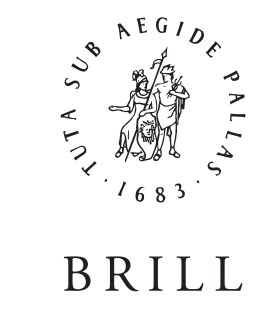

LEIDEN | BOSTON 


\section{Submissions}

For questions and/or submissions please contact the Editors, Bill Reynolds at wrey@georgiasouthern.edu and/or Brad Porfilio at porfilib@seattleu.edu.

Instructions for Authors can be found on the journal website at brill.com/jcml. The Instructions for Authors include details on how to publish on an open access basis with Brill Open.

Brill Open Access options can be found at brill.com/openaccess.

Typeface for the Latin, Greek, and Cyrillic scripts: "Brill”. See and download: brill.com/brill-typeface.

ISSN 2590-0102

E-ISSN 2590-0110

Copyright 2021 by Koninklijke Brill NV, Leiden, The Netherlands.

Koninklijke Brill NV incorporates the imprints Brill, Brill Nijhoff, Brill Hotei, Brill Schöningh, Brill Fink, Brill mentis, Vandenhoeck \& Ruprecht, Böhlau Verlag and V\&R Unipress.

All rights reserved. No part of this publication may be reproduced, translated, stored in a retrieval system, or transmitted in any form or by any means, electronic, mechanical, photocopying, recording or otherwise, without prior written permission from the publisher. Requests for re-use and/or translations must be addressed to Koninklijke Brill NV via brill.com or copyright.com.

Brill has made all reasonable efforts to trace all rights holders to any copyrighted material used in this work. In cases where these efforts have not been successful the publisher welcomes communications from copyright holders, so that the appropriate acknowledgements can be made in future editions, and to settle other permission matters.

This journal is printed on acid-free paper and produced in a sustainable manner. 